\title{
Hand Anthropometry Survey of Female Agricultural Workers for Design of Gender Friendly Equipments
}

\author{
Pooja Sahu ${ }^{1 *}$, Pallavi Porte ${ }^{2}$, V. M. Victor and G. Yadav ${ }^{3}$ \\ ${ }^{1}$ Department of Agricultural Processing and Food Engineering, ${ }^{2}$ Department of Water \\ Resources, ${ }^{3}$ BRSM College of Agril. Engineering and Technology, Indira Gandhi Krishi \\ Viswvidyalaya, Raipur-492012, Chhattisgarh, India
}

*Corresponding author

\section{Keywords}

Anthropometric, Age groups, Hand dimensions, Gender friendly

\section{Article Info}

Accepted:

15 April 2020

Available Online:

10 May 2020
An anthropometric survey of female farm workers was conducted from the Mungeli district, in order to obtain information on the body dimensions, which may be used in ergonomic design of farm equipments. In present study different hand dimensions of right and left hand of 200 female agricultural workers have been collected. Four body dimensions and ten hand dimensions have been identified which were considered more useful for designing agricultural hand tools. It has noted that there were significant differences in hand measurement between left and right hands of agricultural female workers. The 200 female workers were categorized in four different age groups $(18-25,26-$ $35,36-45,46$ to above) whose mean, standard deviation, coefficient of variation (CV), range were computed according to age groups. Percentile values (5th, 25th, 50th, 95th) of the anthropometric dimensions were also computed separately for different age groups. The percentage difference in the measurement between right and left hands was small $(0.05 \%$ to $0.22 \%)$. However, it was common practice of workers to use the same hand tools by both sexes. Therefore, this information of hand anthropometric dimensions of female workers helps us in design of gender friendly equipments and hand tools. The hand dimensions of subjects of the present study were also compared with female workers of central part of India and abroad.

\section{Introduction}

India is an agriculture-based country. A large section of Indian population is involved in agriculture. In central part of India, major agriculture is in paddy cultivation. In Chhattisgarh state a large section of woman labours are associated with paddy cultivation jobs (Census of India, 1991). They use different type of hand tools for various steps of paddy cultivation. Hand tools need to fit the contours of hand; they need to be held securely with suitable wrist and arm posture, they may be utilizing strength and energy capabilities without over loading the body. For effective use of tools and implements that require workers to maintain a power grip during task performance, adequate space must be provided on the handle (Okunribido, 2000). 
Some hand tools require a fairly small force but precise handling and other hand large force but increase handling. Hence, the design of agricultural hand tools is a complex ergonomic task and requires hand anthropometry. In Indian agriculture, hand tools, animal-drawn equipment and tractor/power operated machinery are extensively used for various operations. This equipment are either operated or and controlled by human workers (Gite Yadav, 1989). Use of anthropometric data can help in the proper design of equipment for better efficiency and more human comfort.

Today, there is a growing demand among professional hand tool users to have ergonomically designed products (Schmidtke, 1984; Snow, 1984). Many people need them, but a few know anything about them. If better fitted hand tools or appliance are to be produced for agricultural workers, knowledge of the hand dimensions is required. This information is also useful of determining various aspects of industrial machinery (Imrhan et al., 1993, Lewis and Narayan, 1993). Therefore, it is necessary to have data of Indian agricultural workers, both men and women to assist in proper equipment design.

Considering the socio-economic condition and common habitual practice of the Indian farmers, the design of hand tools having the same dimensions for both men and women may be adopted. For designing such a hand tool the hand measurements of male and female subjects should be taken as the same.

However, it is the common practice, among the Indian agricultural workers to use the same hand tools by the male and female workers. The data of male and female subjects may be used for designing hand tools separately for them. Mismatches between human anthropometric dimensions and equipment dimensions are known to be a contributing factor in decreased productivity, discomfort, accidents, biomechanical stresses, fatigue, injuries, and cumulative traumas. Therefore, various researchers have pointed out the importance of using relevant anthropometric data in equipment design.

The present need for the use of agricultural machineries and equipments for agricultural mechanization require a good knowledge and proper design of agricultural equipment with special consideration to efficiency, safety and comfort of people using them.

In the present study different hand dimensions of right and left hand of 200 agricultural female workers have been collected from Mungeli region. The collected anthropometric data were compared with the data of other part of India and abroad.

\section{Materials and Methods}

\section{Subject}

Measurements were taken from 200 agricultural female workers belonging to four different age groups as 18-25, 26-35, 36-45 and 46 above. The subjects covered under the random survey were the female workers working in different agricultural field of Mungeli District, Chhattisgarh. Fifteen body dimensions were measured from the agricultural machinery and tools design point of view. 200 subjects collected data could be used for design of agricultural machinery to developed ergonomic consciousness for the designers.

\section{Body dimensions agricultural workers}

Fifteen body dimensions have been identified in which ten hand dimensions were considered which is useful for agricultural hand tools design. The body dimensions used in study was summarized as follows: 


\section{Body mass index}

The body mass index (BMI), or Quetelet index, is a measure for human body shape based on an individual's mass and height. A measurement of the relative percentages of fat and muscle mass in the human body, in which mass in kilograms is divided by height in meter squared and the result used as an index of obesity.

\section{Basal metabolic rate}

The rate at which energy is used by an organism at complete rest, measured in humans by the heat given off per unit time, and expressed as the calories released per kilogram of body weight or per square meter of body surface per hour.

\section{Hand length}

The straight distance between root of the palm and tip of the middle finger (Figure 1-b).

\section{Palm length}

The straight distance between root of the palm and root of the middle finger (Figure 1-b).

\section{Hand breadth}

The breadth of the palm measured at the level of maximum buldge of the palm excluding thumb.

\section{Maximum hand breadth}

The breadth of the hand measured at the level of maximum buldge of the palm including thumb (Figure 1-e).

\section{Hand thickness}

The thickness of the hand measure at the level of middle portion of the palm transversely

\section{Hand circumference}

The close measurement that follows a hand contour at the maximum palm level, the measurement is not circular (Figure 1-d).

\section{Maximum hand circumference}

The closed measurement that follows a hand contour at the maximum feast level, the measurement is not circular (Figure 1-a).

\section{Grip diameter}

Maximum inner curvature of the hand at the touching level between tip of the middle finger and thumb (Figure 1-c).

\section{Arm length}

The straight distance between root of the arm and tip of the middle finger (Figure 1-f).

\section{Elbow length}

The straight distance between root of the elbow and tip of the middle finger (Figure 1g).

\section{Instrument}

\section{Body fat monitor}

Through this body fat monitor we calculate body mass index (BMI) and basal metabolic rate (BMR). This instrument is automatic digital instrument shows the values of BMI and BMR on feeding the values of height, age, weight of subject.

\section{Vernier caliper}

A vernier scale is a device that lets the user measure more than could be done by reading a uniformly-divided straight or circular measurement scale. It is scale that indicates 
where the measurement lies in between two of the marks on the main scale. Through this instrument we calculate the hand thickness.

\section{Scale}

Hand length, palm length, hand breadth and maximum hand breadth could be calculate through the scale. We use $30 \mathrm{~cm}$ long scale for finding these dimensions.

\section{Measuring tape}

In this study, it is used for measuring the arm length and elbow length.

\section{Threads}

In this study we used the thread for measuring the hand circumference and maximum hand circumference.

\section{Pipes and bamboos roller}

Different diameters of pipe and bamboo are used for calculation of the grip diameter.
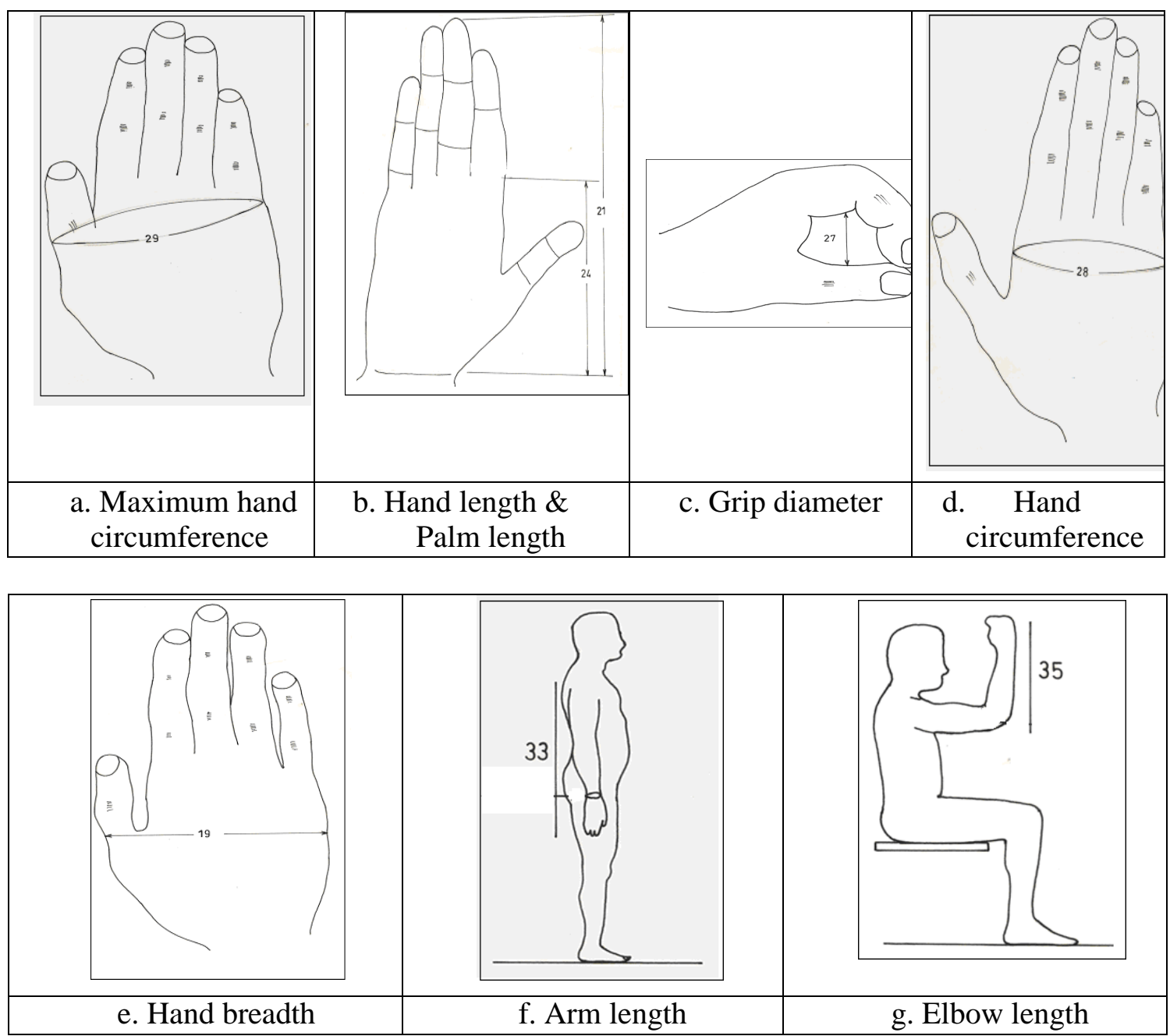

Figure.1 Different hand dimensions 
A200 subjects were evaluated for efficient use of hand tools and equipments of agricultural female workers. The right and left hand of the subject were include the measurement taken under standardized condition and using proper landmark. The following steps are given below:

Firstly, we take body dimension such as age, weight, and height. Weight and height should be taken with the help of weighing machine.

Then, calculate body mass index and basal metabolic rate. The instrument used for calculating body mass index and basal metabolic rate is body fat monitor. For find out the value of BMI and BMR take value in standing position of the subject one by one and put the value of age, weight, height, in which hand angle is at $90^{\circ}$ of particular subject then the instrument gives correct value. The values of BMI are dimensionless and the value of BMR is expressed in kcal.

After that measuring hand length, palm length, hand breadth, maximum hand breadth in cm with the help of scale.

Now, calculate the hand thickness in $\mathrm{cm}$ and the instrument used for find out the hand thickness is Vernier caliper.

Then, measure the hand circumference with the help of thread also in $\mathrm{cm}$.

To find out the hand grip diameter, different diameters of bamboo rollers were used.

At last measure the arm length and elbow length in $\mathrm{cm}$ with the help of measuring tape in standing posture.

\section{Statistical analysis}

Descriptive statistics were summarized in terms of mean, standard deviation (SD) and coefficient of variation $(\mathrm{CV} \%)$. Statistical parameters were computed by using computerized statistical analysis software (SPSS).

\section{Results and Discussion}

Various Anthropometric Measurements had been taken for the designing of Agricultural tools and equipment for the drudgery reduction of Farm women. Further, observations were analyzed STDEV, CV, Range, $5^{\text {th }}, 25^{\text {th }}, 50^{\text {th }}$ and $95^{\text {th }}$ percentile of above anthropometric measurements were calculated.

The variation of hand length dimension of women of age group 18-25 years was found higher $(5 \%)$ than women's' of other age groups whereas the variation in palm length was found higher in women's age group of 46 and above. The standard deviation of breadth, thickness and grip diameter was found below $1 \mathrm{~mm}$ in all age group of women's of the region.

Whereas standard deviation of arm length and elbow length was found more than the mean value of thickness, breadth of women of Chhattisgarh region was coincides with the women of the Central India and standard deviation values of these parameters are within the range of women of Central India and abroad. The handle diameter of hand tools used by the women's of the region within the range of grip diameter of women's of region i.e. $4.2 \mathrm{~cm}$.

Physical characteristics of women between 18-25 age of physical characteristics of agricultural women workers of age group 1825 years are given in the table 1 . The body weight women workers were ranged from 36 to $65 \mathrm{~kg}$ whereas the mean body weight was found to be $49.2 \mathrm{~kg}$. The BMI was found to be ranged of 15.2 to 35.7 and BMR was found to be range from 913 to 1553 . The mean BMI and BMR were found to be 21.3 and 1191.8 respectively. The height of woman workers was ranged from $137-164 \mathrm{~cm}$. 
The data was statistically analyzed shows that there was significant difference in weight and height of agricultural female workers of age group 18-25 years and was found to be highest as 8.1 in weight and lowest in height 6.8 whereas coefficient of variation $(\mathrm{CV})$ was found to be 16.4 per cent and 4.4 in weight and height respectively.

The value of the height, weight, BMI and BMR for 5th percentile woman workers was found to be 39, 140.7, 16.7 and 986.0 respectively. The 25th percentile value of height, weight, BMI and BMR was found to be $45,149.3,18.6$ and 1096 respectively.

The 50th percentile of following parameters was found to be 47, 154.5, 19.8 and 1132 . The 95th percentile of body weight, height, BMR and BMI was found to be $67.75,163.5$, 28.7 and 1512.1 respectively. The percent difference in weight of female workers of age group 18- 25 years was found to be $36-65 \mathrm{~kg}$ with body mass index 21.3 shows the larger workers in this group was oblique in nature.

Physical characteristics of women between 26-35 age Table 2 shows that the body weight of age group 26- 35 was found to be varies from $40-75 \mathrm{~kg}$ whereas the mean body weight was found to be $54.5 \mathrm{~kg}$. The standard deviation for body weight was found as 7.9 and the $\mathrm{CV}$ was found to be 14.6 per cent.

Similarly height varies from 144 to $169 \mathrm{~cm}$ whereas very deviation of 5.3 and $\mathrm{CV}$ was 3.4 per cent was found in height of woman of age group $26-35$ years. The BMI was found to be in the range of 16.5 to 31.9 and BMR was ranges from 935 to 1645 . The value of the height, weight, BMI and BMR for 5th percentile was found to be 43.9, 146, 19.2 and 1026.1 respectively. Similarly body weight, height, BMR and BMI was found to be 67.1, $163.2,28.7$ and 1459.3 respectively for 95th percentile female workers of the region.
Physical characteristics agricultural women workers of age group 36-45 is given in the table 3 shows that the mean body weight was $56.2 \mathrm{~kg}$ and ranged between 39 to $78 \mathrm{~kg}$. Table shows that standard deviation for weight was found as 8.7 and the CV was 15.4 per cent.

Similarly the height of female workers ranges from 140 to $170 \mathrm{~cm}$ and standard deviation was found as 6.3 whereas $\mathrm{CV}$ was 4.1 per cent. The BMI is the parameter of body weight and height of the female worker and it was found to be in the range of 17.7 to 42.5 with 24.3 mean BMI of woman of age group 36-45 age. Similarly BMR was found to be in the range of 918 to 2027 . The mean of the BMR was found to be 1225.3. The standard deviation for BMR was found as 197.0 and the $\mathrm{CV}$ was 16.1 per cent. The value of the height, weight, BMI and BMR was found to be $45.3,145,18.4$ and 1025.0 and $72.1,163.7$, 29.8 and 1507.7 respectively for 5th and 95th percentile workers of the region.

Physical characteristics of 50 agricultural women workers between ages 46 to above are given in the table 4 . The Body weight was found to be in the range of 40 to 81 . The mean of the body weight was found to be 60.2. The standard deviation for weight was found as 9.7 and the CV was 16.1 per cent. The range for the height was found as 137 to 168. Mean of height was found to be 154.0.

The standard deviation for height was found as 5.3 and the $\mathrm{CV}$ was 3.4 per cent. The BMI was found to be in the range of 19.4 to 31.6. The mean of the BMI was found to be 25.2. The standard deviation for BMI was found as 3.6 and the CV was 14.4 per cent. . The BMR was found to be in the range of 887 to 1624 . The mean of the BMR was found to be 1236.9. The standard deviation for BMR was found as 163.2 and the CV was 13.2 per cent. 
The 5th percentile value of the height, weight, BMI and BMR was found to be 46, 146.5, 19.9 and 956.6 respectively. The 25th percentile value of height, weight, BMI and BMR was found to be 51.5, 150, 21.9 and 1121.7 respectively. The 50th percentile of following parameters was found to be 59.5, 154, 25.4 and 1213.5. The 95th percentile of body weight, height, BMR and BMI was found to be 74.6, 162.6, 30.7 and 1476.3 respectively. Hand dimensions of agricultural women of age group 18-25 in table 5 of right and left hand parameter for 50 agricultural women workers. The $\mathrm{CV}$ of palm length variation between Left and right hand is 0.6. Maximum hand breadth variation between left and right hand is 0.8 . The hand thickness variation between Left and right hand is 0.7 . Maximum hand circumference variation between left and right hand is 0.1. The arm length was found to be 0.6 .

Hand dimensions of agricultural women for age group 26-35 in table 6 of right and left hand parameter for 50 agricultural women workers. The $\mathrm{CV}$ of palm length variation between Left and right hand is 0.2. The hand breadth variation between Left and right hand is 0.4. Maximum hand breadth variation between Left and right hand is 0.2. The hand circumference variation between Left and right hand is 0.1. Maximum hand circumference and grip diameter variation between Left and right hand is 0.1 .

Hand parameters of agricultural women for age group 36-45 in table 7 of right and left hand parameter such as the $\mathrm{CV}$ of hand length, the variation between Left and right hand is 0.3 . The hand breadth and maximum hand breadth variation between Left and right hand is 0.7 and 0.1 respectively. The hand thickness variation between Left and right hand is 0.2. The hand circumference and grip diameter variation between Left and right hand is 0.1 both. The maximum hand circumference variation between Left and right hand is 0.1 and also the elbow length was found to be 0.1 .

Hand parameters of agricultural women for age group 46 to above in table 8 of right and left hand parameter for 50 agricultural women workers. The $\mathrm{CV}$ of hand length and palm length variation between Left and right hand is 0.1 and 0.3 respectively. The hand breadth and maximum hand breadth variation between Left and right hand is 0.1 and 0.4. The hand thickness variation between Left and right hand is 0.1 . The elbow length was found to be 0.1 .

India is an agriculture based country. Large section of Indian population is involved in agriculture. Paddy is the major crop of the Chhattisgarh and about $70 \%$ of field operation and paddy was carried out by women workers. In regular work human being use a variety of equipment, included hand tools, to accomplished various task. Such equipment should be compatible with the physical characteristics of the workers. Hand tools need to fit the contours of hand, they may be utilizing strength and energy capabilities without overloading the body. Mismatches between human anthropometric dimensions and equipment dimensions are known to be a contributing factor in decreased productivity, discomfort, accidents, fatigue, injuries.

According to this point of view, we have measured body and hand dimensions for agricultural female workers in field for accurate and uniformly designed agricultural hand tools for comfortably used by women workers. For that, anthropometric and strength data have greatest importance in designed and development of farm implements (Table 9 and 10). 
Table.1 Physical characteristics of female workers of age group 18-25 age

\begin{tabular}{|c|c|c|c|c|c|c|c|}
\hline Parameters & Mean \pm SD & CV\% & Range & & Percenti & & \\
\hline & & & & $5^{\text {th }}$ & $25^{\text {th }}$ & $50^{\text {th }}$ & $95^{\text {th }}$ \\
\hline Age, year & $21.4 \pm 2.4$ & 11.0 & $18-25$ & 18 & 20 & 21 & 25 \\
\hline Body weight, kg & $49.2 \pm 8.1$ & 16.4 & $36-65$ & 39.0 & 45.0 & 47.0 & 67.75 \\
\hline Height, cm & $153.6 \pm 6.8$ & 4.4 & $137-164$ & 140.7 & 149.3 & 154.5 & 163.5 \\
\hline $\begin{array}{l}\text { Body mass index } \\
\text { (BMI) }\end{array}$ & $21.3 \pm 4.1$ & 19.1 & $\begin{array}{l}15.2- \\
35.7\end{array}$ & 16.7 & 18.6 & 19.8 & 28.7 \\
\hline $\begin{array}{l}\text { Basal metabolic } \\
\text { rate (BMR) }\end{array}$ & $\begin{array}{c}1191.8 \pm \\
184.1\end{array}$ & 15.4 & $\begin{array}{l}913- \\
1553\end{array}$ & 986.0 & 1096.0 & 1132.0 & 1512.0 \\
\hline
\end{tabular}

Table.2 Physical characteristics of women between 26-35 age

\begin{tabular}{|l|c|c|c|c|c|c|c|}
\hline Parameters & Mean $\mathbf{E}$ SD & CV\% & Range & \multicolumn{4}{|c|}{ Percentile } \\
\cline { 5 - 9 } & & & & $\mathbf{5}^{\text {th }}$ & $\mathbf{2 5}^{\text {th }}$ & $\mathbf{5 0}^{\text {th }}$ & $\mathbf{9 5}^{\text {th }}$ \\
\hline Age, year & $29.8 \pm 3.2$ & 10.6 & $26-35$ & 26 & 27 & 29.5 & $\mathbf{3 5}$ \\
\hline Body weight, kg & $54.5 \pm 7.9$ & 14.6 & $40-75$ & 43.9 & 48.0 & 54.0 & $\mathbf{6 7 . 1}$ \\
\hline Height, cm mass & $154.2 \pm 5.3$ & 3.4 & $144-169$ & 146.0 & 151.0 & 155.0 & $\mathbf{1 6 3 . 2}$ \\
\hline $\begin{array}{l}\text { Body } \\
\text { index(BMI) }\end{array}$ & $23.0 \pm 3.1$ & 13.6 & $16.5-31.9$ & 19.2 & 20.8 & 22.5 & $\mathbf{2 8 . 7}$ \\
\hline $\begin{array}{l}\text { Basal metabolic } \\
\text { rate (BMR) }\end{array}$ & $\begin{array}{c}\mathbf{1 2 2 7 . 5} \pm \\
\mathbf{1 3 8 . 7}\end{array}$ & $\mathbf{1 1 . 3}$ & $\mathbf{9 3 5 - 1 6 4 5}$ & $\mathbf{1 0 2 6 . 1}$ & $\mathbf{1 1 3 2}$ & $\mathbf{1 2 2 2}$ & $\mathbf{1 4 5 9 . 3}$ \\
\hline
\end{tabular}

Table.3 Physical characteristics of women of age group 36-45 years

\begin{tabular}{|c|c|c|c|c|c|c|c|}
\hline \multirow[t]{2}{*}{ Parameters } & \multirow[t]{2}{*}{ Mean \pm SD } & \multirow[t]{2}{*}{ CV\% } & \multirow[t]{2}{*}{ Range } & \multicolumn{4}{|c|}{ Percentile } \\
\hline & & & & $5^{\text {th }}$ & $25^{\text {th }}$ & $50^{\text {th }}$ & $95^{\text {th }}$ \\
\hline Age, year & $39.9 \pm 3.0$ & 7.4 & $36-45$ & 36 & 37 & 40 & 44 \\
\hline Body weight, kg & $56.2 \pm 8.7$ & 15.4 & $39-78$ & 45.3 & 49 & 55 & 72.1 \\
\hline Height, cm & $153.2 \pm 6.3$ & 4.1 & $140-170$ & 145 & 148 & 153 & 163.7 \\
\hline Body mass index (BMI) & $24.3 \pm 4.2$ & 17.4 & $17.7-42.5$ & 18.4 & 22.2 & 23.7 & 29.8 \\
\hline $\begin{array}{l}\text { Basal metabolic rate } \\
\text { (BMR) }\end{array}$ & $1225.3 \pm 197.0$ & 16.1 & 918-2027 & 1025.0 & 1086 & 1187 & 1507.7 \\
\hline
\end{tabular}


Table.4 Physical characteristics of women of age group $>45$ years

\begin{tabular}{|c|c|c|c|c|c|c|c|}
\hline \multirow[t]{2}{*}{ Parameters } & \multirow[t]{2}{*}{ Mean \pm SD } & \multirow[t]{2}{*}{ CV\% } & \multirow[t]{2}{*}{ Range } & \multicolumn{4}{|c|}{ Percentile } \\
\hline & & & & $5^{\text {th }}$ & $25^{\text {th }}$ & $50^{\text {th }}$ & $95^{\text {th }}$ \\
\hline Age, year & $50.9 \pm 3.4$ & 6.7 & $>46$ & 46.4 & 48 & 51 & 57 \\
\hline Body weight, kg & $60.2 \pm 9.7$ & 16.1 & $40-81$ & 46 & 51.5 & 59.5 & 74.6 \\
\hline Height, cm & $154.0 \pm 5.3$ & 3.4 & $137-168$ & 146.5 & 150 & 154 & 162.6 \\
\hline Body mass index(BMI) & $25.2 \pm 3.6$ & 14.4 & 19.4-31.6 & 19.9 & 21.9 & 25.4 & 30.7 \\
\hline Basal metabolic rate (BMR) & $1236.9 \pm 163.2$ & 13.2 & $887-1624$ & 956.6 & 1121.7 & 1213.5 & 1476.3 \\
\hline
\end{tabular}

Table.5 Hand dimensions of women of age group 18-25 years

\begin{tabular}{|c|c|c|c|c|c|c|c|c|c|c|c|c|c|c|}
\hline \multirow[t]{3}{*}{ Parameters } & \multirow{2}{*}{\multicolumn{2}{|c|}{ Mean \pm SD }} & \multirow{2}{*}{\multicolumn{2}{|c|}{ CV\% }} & \multirow{2}{*}{\multicolumn{2}{|c|}{ Range }} & \multicolumn{8}{|c|}{ PERCENTILE } \\
\hline & & & & & & & \multicolumn{2}{|c|}{$5^{\text {th }}$} & \multicolumn{2}{|c|}{$25^{\text {th }}$} & \multicolumn{2}{|c|}{$50^{\text {th }}$} & \multicolumn{2}{|c|}{$95^{\text {th }}$} \\
\hline & RH & $\mathrm{LH}$ & RH & LH & RH & LH & RH & LH & RH & LH & RH & LH & RH & LH \\
\hline Hand Length,cm & $17.5 \pm 0.9$ & $17.5 \pm 0.9$ & 5.2 & 5.1 & $15.4-19.5$ & $15.5-19.6$ & 15.7 & 15.8 & 16.6 & 16.8 & 17.5 & 17.4 & 18.4 & 18.5 \\
\hline Palm Length,cm & $9.8 \pm 0.6$ & $9.8 \pm 0.6$ & 6.1 & 6.7 & $7.4-11.0$ & $7.4-10.8$ & 9.1 & 9.0 & 9.5 & 9.4 & 9.9 & 9.9 & 10.6 & 10.7 \\
\hline $\begin{array}{l}\text { Hand Breadth, } \\
\text { cm }\end{array}$ & $7.4 \pm 0.4$ & $7.4 \pm 0.4$ & 5.3 & 5.0 & $6.5-10.4$ & $6.7-10.5$ & 6.7 & 6.6 & 7.2 & 7.2 & 7.4 & 7.4 & 8.0 & 8.0 \\
\hline $\begin{array}{l}\text { Maximum Hand } \\
\text { Breadth, cm }\end{array}$ & $9.1 \pm 0.5$ & $9.0 \pm 0.6$ & 5.4 & 6.2 & $8.1-10.1$ & $8.0-10.4$ & 8.3 & 8.1 & 8.6 & 8.6 & 9.1 & 9.0 & 10 & 9.9 \\
\hline $\begin{array}{l}\text { Hand } \\
\text { Thickness,cm }\end{array}$ & $2.6 \pm 0.4$ & $2.6 \pm 0.3$ & 13.6 & 12.9 & $1.8-3.6$ & $1.8-3.5$ & 2.1 & 2.0 & 2.4 & 2.4 & 2.6 & 2.6 & 3.1 & 3.0 \\
\hline Hand Circum,cm & $19.2 \pm 1.3$ & $19.2 \pm 1.3$ & 6.7 & 6.7 & $16.3-22.0$ & $16.0-22.0$ & 17.2 & 17.4 & 18.4 & 18.5 & 19.2 & 19.2 & 21.8 & 21.7 \\
\hline $\begin{array}{l}\text { MaxHand } \\
\text { Circum,cm }\end{array}$ & $22.1 \pm 1.1$ & $22.1 \pm 1.1$ & 5.1 & 5.0 & $18.9-23.8$ & $19.4-25.0$ & 20.8 & 20.8 & 21.4 & 21.3 & 22.0 & 22.0 & 23.6 & 23.5 \\
\hline $\begin{array}{l}\text { Grip } \\
\text { Diameter,cm }\end{array}$ & $4.4 \pm 0.4$ & $4.4 \pm 0.5$ & 12.7 & 12.9 & $2.39-5.08$ & $1.56-5.08$ & 3.8 & 3.8 & 4.5 & 4.5 & 4.7 & 4.7 & 5.1 & 5.1 \\
\hline Arm Length,cm & $69.7 \pm 3.9$ & $69.3 \pm 4.2$ & 5.5 & 6.1 & $60.5-76.0$ & $60.3-75.9$ & 61.7 & 60.9 & 67.5 & 67.0 & 70.2 & 70.0 & 74.6 & 74.6 \\
\hline Elbow Length,cm & $42.6 \pm 2.3$ & $42.6 \pm 2.3$ & 5.3 & 5.3 & $37.9-47.0$ & $38.0-47.0$ & 39.5 & 39.6 & 40.9 & 41.0 & 42.3 & 42.2 & 46.0 & 46.1 \\
\hline
\end{tabular}


Table.6 Different hand dimensions of women between 26-35 age

\begin{tabular}{|c|c|c|c|c|c|c|c|c|c|c|c|c|c|c|}
\hline \multirow[t]{3}{*}{ Parameters } & \multirow{2}{*}{\multicolumn{2}{|c|}{ Mean \pm SD }} & \multirow{2}{*}{\multicolumn{2}{|c|}{ CV\% }} & \multirow{2}{*}{\multicolumn{2}{|c|}{ Range }} & \multicolumn{8}{|c|}{ PERCENTILE } \\
\hline & & & & & & & \multicolumn{2}{|l|}{$5^{\text {th }}$} & \multicolumn{2}{|c|}{$25^{\text {th }}$} & \multicolumn{2}{|c|}{$50^{\text {th }}$} & \multicolumn{2}{|c|}{$95^{\text {th }}$} \\
\hline & $\mathrm{RH}$ & LH & RH & LH & RH & LH & RH & LH & RH & LH & RH & LH & RH & LH \\
\hline Hand Length,cm & $17.4 \pm 0.8$ & $17.4 \pm 0.8$ & 4.8 & 4.8 & $15.7-19.1$ & $15.6-19.5$ & 16.1 & 16.1 & 16.8 & 16.9 & 17.3 & 17.2 & 18.8 & 18.8 \\
\hline Palm Length,cm & $9.8 \pm 0.5$ & $9.8 \pm 0.5$ & 5.2 & 5.4 & $8.5-11.0$ & 8.4-11.1 & 9.0 & 8.9 & 9.5 & 9.5 & 9.9 & 9.8 & 10.5 & 10.6 \\
\hline $\begin{array}{l}\text { Hand } \\
\text { Breadth,cm }\end{array}$ & $7.5 \pm 0.4$ & $7.5 \pm 0.4$ & 5.8 & 5.4 & $6.4-8.4$ & $6.4-8.4$ & 6.9 & 7.0 & 7.3 & 7.2 & 7.5 & 7.5 & 8.2 & 8.1 \\
\hline $\begin{array}{l}\text { Maximum } \\
\text { Hand } \\
\text { Breadth, } \\
\text { cm }\end{array}$ & $9.1 \pm 0.6$ & $9.1 \pm 0.6$ & 6.6 & 6.4 & $7.4-10.3$ & $8.0-10.2$ & 8.1 & 8.2 & 8.8 & 8.8 & 9.1 & 9.0 & 10.2 & 10.0 \\
\hline $\begin{array}{l}\text { Hand } \\
\text { Thickness,cm }\end{array}$ & $2.7 \pm 0.3$ & $2.6 \pm 0.3$ & 12.3 & 12.6 & $0-3.2$ & $2.0-3.5$ & 2.1 & 2.1 & 2.4 & 2.4 & 2.6 & 2.6 & 3.1 & 3.1 \\
\hline $\begin{array}{l}\text { Hand } \\
\text { Circum,cm }\end{array}$ & $19.8 \pm 1.1$ & $19.7 \pm 1.1$ & 5.4 & 5.5 & $17.1-22.0$ & 17.3-21.9 & 18.3 & 18.0 & 19.0 & 19.0 & 19.7 & 19.8 & 21.8 & 21.7 \\
\hline $\begin{array}{l}\text { Maximum } \\
\text { HandCircum, } \\
\text { cm }\end{array}$ & $22.5 \pm 1.0$ & $22.4 \pm 1.0$ & 4.6 & 4.5 & $20.0-24.4$ & $19.8-24.8$ & 20.7 & 20.8 & 22.0 & 21.8 & 22.5 & 22.5 & 23.8 & 23.7 \\
\hline $\begin{array}{l}\text { Grip } \\
\text { Diameter,cm }\end{array}$ & $4.4 \pm 0.3$ & $4.4 \pm 0.3$ & 10.0 & 9.9 & $3.81-5.08$ & $3.81-5.08$ & 4.0 & 4.0 & 4.7 & 4.7 & 4.7 & 4.7 & 5.0 & 5.0 \\
\hline $\begin{array}{l}\text { Arm Length, } \\
\text { cm }\end{array}$ & $69.8 \pm 4.1$ & $69.8 \pm 4.1$ & 5.9 & 5.9 & $56.9-79.0$ & $57-77.9$ & 64.0 & 63.9 & 67.6 & 67.6 & 70.0 & 70.0 & 76.6 & 76.9 \\
\hline $\begin{array}{l}\text { Elbow Length, } \\
\mathrm{cm}\end{array}$ & $43.4 \pm 2.3$ & $43.4 \pm 2.2$ & 5.2 & 5.2 & $39.0-49.0$ & 38.8-49.0 & 40.0 & 39.9 & 42.0 & 42.0 & 43.0 & 43.1 & 47.0 & 47.0 \\
\hline
\end{tabular}


Table.7 Different hand dimensions of women between 36-45 age

\begin{tabular}{|c|c|c|c|c|c|c|c|c|c|c|c|c|c|c|}
\hline \multirow[t]{3}{*}{ Parameters } & \multirow{2}{*}{\multicolumn{2}{|c|}{ Mean \pm SD }} & \multirow{2}{*}{\multicolumn{2}{|c|}{ CV\% }} & \multirow{2}{*}{\multicolumn{2}{|c|}{ Range }} & \multicolumn{8}{|c|}{ PERCENTILE } \\
\hline & & & & & & & \multicolumn{2}{|l|}{$5^{\text {th }}$} & \multicolumn{2}{|l|}{$25^{\text {th }}$} & \multicolumn{2}{|l|}{$50^{\text {th }}$} & \multirow{2}{*}{$\begin{array}{l}\text { 95 }^{\text {th }} \\
\mathrm{RH}\end{array}$} & \multirow[b]{2}{*}{ LH } \\
\hline & RH & LH & RH & LH & RH & LH & RH & LH & RH & LH & RH & LH & & \\
\hline Hand Length,cm & $17.2 \pm 0.8$ & $17.3 \pm 0.8$ & 4.8 & 4.5 & $14.6-19.1$ & $14.8-19$ & 16.0 & 16.1 & 16.7 & 16.9 & 17.2 & 17.3 & 18.6 & 18.6 \\
\hline Palm Length,cm & $9.6 \pm 0.6$ & $9.7 \pm 0.6$ & 5.9 & 5.9 & $8.5-11.0$ & $8.6-11.1$ & 8.8 & 8.8 & 9.2 & 9.1 & 9.8 & 9.7 & 10.7 & 10.6 \\
\hline Hand Breadth,cm & $7.4 \pm 0.5$ & $7.4 \pm 0.4$ & 6.7 & 6.0 & $6.5-8.9$ & $6.6-8.9$ & 6.8 & 6.8 & 7.1 & 7.1 & 7.3 & 7.4 & 8.4 & 8.2 \\
\hline $\begin{array}{l}\text { Maximum Hand } \\
\text { Breadth, cm }\end{array}$ & $9.2 \pm 0.6$ & $9.2 \pm 0.6$ & 6.3 & 6.5 & 7.6-10.9 & $7.6-8.0$ & 8.2 & 8.1 & 9.0 & 9.0 & 9.2 & 9.2 & 10.2 & 10.0 \\
\hline Hand Thickness,cm & $2.5 \pm 0.3$ & $2.5 \pm 0.3$ & 13.4 & 13.2 & $2.0-3.2$ & $2.0-3.1$ & 2.0 & 2.0 & 2.2 & 2.2 & 2.5 & 2.5 & 3.0 & 3.0 \\
\hline Hand Circum,cm & $19.2 \pm 1.1$ & $9.1 \pm 1.1$ & 5.5 & 5.6 & $17.1-22$ & $17.0-21.4$ & 17.6 & 17.6 & 18.3 & 18.3 & 19.0 & 19.0 & 21.0 & 20.8 \\
\hline Grip Diameter,cm & $4.2 \pm 0.5$ & $4.2 \pm 0.5$ & 12.3 & 12.4 & $3.17-5.08$ & $3.17-5.08$ & 3.6 & 3.6 & 4.2 & 4.2 & 4.7 & 4.7 & 5.0 & 5.0 \\
\hline Arm Length, cm & $70.0 \pm 3.4$ & $70.0 \pm 3.4$ & 4.8 & 4.8 & $62.0-79.0$ & $61.0-76.9$ & 65.0 & 65.5 & 68.1 & 68.0 & 70.0 & 70.0 & 75.5 & 75.3 \\
\hline $\begin{array}{l}\text { Elbow Length, } \\
\text { cm }\end{array}$ & $42.1 \pm 2.2$ & $42.1 \pm 2.1$ & 5.1 & 5.0 & $38.1-47.0$ & 38.1-46.9 & 39.0 & 39.0 & 40.3 & 40.5 & 41.8 & 41.6 & 46.0 & 45.9 \\
\hline
\end{tabular}

Table.8 Different hand dimensions of women between 46 to above age

\begin{tabular}{|c|c|c|c|c|c|c|c|c|c|c|c|c|c|c|}
\hline \multirow[t]{3}{*}{ Parameters } & \multirow{2}{*}{\multicolumn{2}{|c|}{ Mean \pm SD }} & \multirow{2}{*}{\multicolumn{2}{|c|}{ CV\% }} & \multirow{2}{*}{\multicolumn{2}{|c|}{ Range }} & \multicolumn{8}{|c|}{ PERCENTILE } \\
\hline & & & & & & & \multicolumn{2}{|l|}{$5^{\text {th }}$} & \multicolumn{2}{|l|}{$25^{\text {th }}$} & \multicolumn{2}{|l|}{$50^{\text {th }}$} & \multirow{2}{*}{$\begin{array}{l}\mathbf{9 5}^{\text {th }} \\
\text { RH }\end{array}$} & \multirow[b]{2}{*}{ LH } \\
\hline & RH & LH & RH & LH & RH & LH & RH & LH & RH & LH & RH & LH & & \\
\hline Hand Length,cm & $17.8 \pm 0.7$ & $17.8 \pm 0.7$ & 3.7 & 3.8 & $16.5-19$ & 16.4-19 & 16.7 & 16.6 & 17.5 & 17.4 & 18.0 & 17.9 & 18.8 & 18.9 \\
\hline Palm Length,cm & $9.4 \pm 0.7$ & $9.4 \pm 0.7$ & 7.6 & 7.9 & $7.5-11.0$ & $7.6-10.9$ & 8.1 & 8.1 & 9.0 & 9.0 & 9.3 & 9.2 & 10.5 & 10.6 \\
\hline Hand Breadth,cm & $7.2 \pm 0.4$ & $7.2 \pm 0.4$ & 5.5 & 5.4 & $6.7-10.2$ & $6.6-10.0$ & 6.5 & 6.6 & 7.0 & 6.9 & 7.2 & 7.1 & 7.9 & 7.9 \\
\hline $\begin{array}{l}\text { Maximum } \\
\text { HandBreadth, cm }\end{array}$ & $9.0 \pm 0.5$ & $9.0 \pm 0.5$ & 5.5 & 5.9 & $8.1-10.5$ & $7.7-10.5$ & 8.1 & 8.1 & 8.6 & 8.6 & 9.1 & 9.1 & 9.7 & 9.9 \\
\hline Hand Thickness,cm & $2.5 \pm 0.3$ & $2.5 \pm 0.3$ & 12.8 & 12.9 & $2.0-3.1$ & $2.0-3.1$ & 2.1 & 2.0 & 2.2 & 2.2 & 2.5 & 2.5 & 3.0 & 3.0 \\
\hline Hand Circum,cm & $18.8 \pm 0.9$ & $18.8 \pm 0.9$ & 4.5 & 4.5 & $17.7-21.2$ & $17.2-20.6$ & 17.8 & 17.7 & 18.3 & 18.2 & 18.6 & 18.5 & 20.5 & 20.5 \\
\hline $\begin{array}{l}\text { Maximum } \\
\text { HandCircum, cm }\end{array}$ & $22.3 \pm 1.2$ & $22.3 \pm 1.2$ & 5.5 & 5.5 & $20.1-25.0$ & $20.0-24.8$ & 20.8 & 20.7 & 21.4 & 21.4 & 22.0 & 22.1 & 24.9 & 24.8 \\
\hline Grip Diameter,cm & $4.6 \pm 0.4$ & $4.6 \pm 0.4$ & 9.3 & 9.3 & $3.38-5.08$ & $3.38-5.08$ & 3.8 & 3.8 & 4.5 & 4.5 & 4.7 & 4.7 & 5.1 & 5.1 \\
\hline Arm Length, cm & $70.3 \pm 2.8$ & $70.3 \pm 2.8$ & 4.0 & 4.0 & $62.0-76.8$ & $61.9-77.0$ & 65.5 & 65.5 & 69.0 & 69.0 & 70.0 & 70.0 & 75.9 & 75.8 \\
\hline Elbow Length, cm & $42.4 \pm 1.9$ & $42.4 \pm 1.9$ & 4.5 & 4.4 & $39.0-46.5$ & $39.0-46.8$ & 39.9 & 39.9 & 41.0 & 40.9 & 42.0 & 42.0 & 46.0 & 45.7 \\
\hline
\end{tabular}


Table.9 Comparison of percent difference in the value of right and left hand dimension of workers of present study and Central India

\begin{tabular}{|c|c|c|c|c|c|c|}
\hline \multirow[t]{2}{*}{ Hand Dimensions } & \multicolumn{2}{|c|}{ Present study } & \multicolumn{2}{|c|}{ Central India } & \multicolumn{2}{|c|}{$\%$ difference } \\
\hline & $\begin{array}{l}\text { Right } \\
\text { hand }\end{array}$ & Left hand & Right hand & Left hand & Right hand & Left hand \\
\hline Hand Length, cm & 17.50 & 17.50 & 16.09 & 16.06 & 8.77 & 8.99 \\
\hline Palm Length, cm & 9.67 & 9.66 & 8.85 & 8.82 & 9.28 & 9.53 \\
\hline Hand Breadth, cm & 7.38 & 7.37 & 7.3 & 7.07 & 1.15 & 4.25 \\
\hline $\begin{array}{l}\text { Maximum } \\
\text { Breadth, cm }\end{array}$ & 9.08 & 9.07 & 8.75 & 8.64 & 3.82 & 4.92 \\
\hline Hand Thickness, cm & 2.57 & 2.56 & 2.58 & 2.49 & 0.50 & 2.91 \\
\hline $\begin{array}{l}\text { Hand Circumference, } \\
\text { cm }\end{array}$ & 19.24 & 19.20 & 17.8 & 17.32 & 8.10 & 10.87 \\
\hline $\begin{array}{l}\text { Maximum Hand } \\
\text { Circumference, cm }\end{array}$ & 22.31 & 22.28 & 24.48 & 23.88 & 8.88 & 6.70 \\
\hline Grip Diameter, cm & 4.41 & 4.40 & 4.8 & 4.85 & 8.21 & 9.20 \\
\hline
\end{tabular}

Table.10 Comparison of percent difference value of hand dimensions of workers of present study and Central India with Korean Female workers

\begin{tabular}{|l|c|c|c|}
\hline Hand Dimensions & Present study & Korean & \% difference \\
\hline Hand Length, Cm & 17.50 & 17.00 & $\mathbf{2 . 9 5}$ \\
\hline Palm Length, Cm & 9.67 & - & - \\
\hline Hand Breadth, cm & 7.38 & 7.70 & $\mathbf{4 . 1 9}$ \\
\hline Maximum Hand Breadth, cm & 9.07 & 9.00 & $\mathbf{0 . 8 3}$ \\
\hline Hand Thickness, cm & 2.56 & 3.00 & $\mathbf{1 4 . 5}$ \\
\hline Hand Circumference, cm & 19.22 & - & - \\
\hline Maximum Hand Circumference, cm & $\mathbf{2 2 . 2 9}$ & - & - \\
\hline
\end{tabular}

The 200 agricultural female worker anthropometric data collected during survey in Mungeli region. Then the anthropometric data have been analyzed and evaluate the mean, $\mathrm{SD}, \mathrm{CV}$, percentile value through the computerized statically software system. The variation is matching with the actual data of hand tools equipment for agricultural women workers. These results suggest that it is essential to incorporate accurate anthropometry in the design process, as well as in the application of agricultural hand tools equipments.

\section{References}

Agrawal, K.N., Singh, R.K.P. and Satapthy,
K.K (2010). "Anthropometric considerations for farm tools/ machinery design for tribal workers of north eastern India". Agricultural Engineering International: the CIGR Ejournal, Manuscript MES 140. XII: pp. 1-1.

Barut Cagatay, Demirel Pinar, Kiran Sibal (2008). "Evolution of hand anthropomeric measurements and grip strength in basketball volleyball and handball players". Anatomy international journal of experimental and clinical anatomy, 2: pp. 55-59.

Census of India (1991). District Census Hand Book, Midnapore District, Village And Town Wise Primary Census Abstract. 
Directorate of Census Operation, West Bengal Series-26 West Bengal, Part XIII-B.

Chandra Arunesh, Chandan Pankaj and Deswal Suriender (2009). "Hand anthropomeric dimension of male industrial worker of Haryana state". International Journal of Engineering (IJE), 5: pp. 242.

Drakopoulas, D, and Mann, D.D (2007). “An ergonomic analysis of control present in a tractor work station". Canadian biosystems engineering, 49: pp. 2.152.21 .

Gite, L.P. and Yadav, B.G. (1989). "Anthropometric survey for agricultural machinery design". Applied Ergonomics, 20: 191-196.

Gite, L.P. and Yadav, Rajvir(2010). "Analytical study of strength parameter of Indian farm workers and its implications in equipment design". Agricultural Engineering International, the CIGR Ejournal: XII.

Gite, L.P., Majumder, J., Mehta, C.R. and Khadatkar Abhijit (2009).

"Anthropometric And Strength Data Of Indian Agricultural Workers For Farm Equipment Design". Central Institute of Agricultural Engineering Bhopal, India: 15-143.

Imrahan, S.N., Nguyan, M., and Nguyan, N. (1993). "Hand Anthropometry of Americans Vietamese Orgin". International Journal of Industrial Ergonomics, 12: 281-287.

Kar Sanjit Kumar, Ghosh Seem, Monna Indranil, Banerjee Sumanta and Dhara Prakash (2003). "An investigation of hand anthropometry of agricultural workers". J. Hum. Ecol, 14(1): pp57-62.

Klamklay Jaruwan and Sangkhapong Angoon (1990). Anthropometry of Thai Population. Department of Industrial Engineering, Faculty of Engineering, Prince of Songkla University, Hat-Yai,
Songkla 90110 Thailand.

Krishan Kewal (2008). "Estimation of stature from cephalo-facial anthropometry in north Indian population". Forensic Science International, 18: pp. 51.e252.e6.

Kumar, V. J. F. and C. Divakar Duraira March (1992). Development and Evaluation of Weeder Simulation Test Rig for Estimating Operators Fatigue. Indian Journal of Agricultural Engineering, 2(1): pp. 1-11.

Mandahawi Nabeel, Imrhan Sheik, Alshobaki Salman, Sarder B (2008). "Hand anthropometry survey for the Jordanian population". International Journal of Industrial Ergonomics, 38: pp. 966-976.

Murrel, K.F.H. (1979)."Ergonomics - Man in his Working Environment". Chapman and Hall, London.

Nag Anjali, Nag, P.K. and Desai Hina (2003). "Hand anthropometry of Indian women". Indian J Med Res, 117: pp. 260-269

Nkaini, S.O., Akor, A.J., Ayotamuno J.M (2008). "Ergonomics of tractor operation control for comfort in Nigeria”. pp. 4-24.

Nussbaum Maury A., Kroemer Karl H.E. and Wajcik Laura (1993). "Finger force capability: Measurement and prediction using anthropometric and myoelecric measures". pp. 1-103.

Okunribido, O.O. (2002). "A survey of hand anthropometry of female rural farm workers in Ibadan, Western Nigeria". Ergonomics, 43: 282-292.

Onuoha, S.N., Indike, F.I. and Oduma, O (2012). "Anthropometry of south eastern nigeria agricultural workers". International Journal of Engineering and Technology, 2(6): pp. 1089-1095.

Pattersion, Patrick E., Klamklay Jaruwan and Angoon Sangkhapong (1980s and 1990s) . "Anthropometry of thai 
population".

Singh, S. P., Singh, Pratap and Singh, Surendra (2012). "Isometric Torque Affected By its Position and Posture". Agric Eng Int: CIGR Journal, 14: pp. 29.

Schmidtke, H. (1984). Ergonomics and equipment design. NATO Conference series, Series. Series III: In: Ergonomics data for equipment design. Human Factor, 25: 19-23.

Van Wely, P. Design and Disease (1970). Applied Ergonomics, 1(5): pp. 262-269.

Victor, V.M. (2000). Design and Development of Power Operated Rotary Weeder for Wetland Rice. Department of Farm Implement And Machine Faculty of Agricultural Engineering,
Indira Gandhi Agricultural University, Raipur (M.P.) : 24- 27.

Victor, V.M., Nath Saswati and Verma Ajay (1999). Anthropometry studies of female farm workers on selected tasks for agricultural mechanization in Chhattisgarh region. Faculty of Agricultural Engineering, Indira Gandhi Agricultural University, Raipur (c.g.)592012.

Vyavahare, Ravindra Tatyasaheb and Kallurkar, Shrikant (2012). Anthopometric and strength data of Indian Agricultural Workers for Equipment Design: A Review. Agric Eng Int: CIGR Journal, 14(4):12-14.

\section{How to cite this article:}

Pooja Sahu, Pallavi Porte, V. M. Victor and Yadav, G. 2020. Hand Anthropometry Survey of Female Agricultural Workers for Design of Gender Friendly Equipments. Int.J.Curr.Microbiol.App.Sci. 9(05): 2191-2204. doi: https://doi.org/10.20546/ijcmas.2020.905.250 